\title{
Tratamento de ruptura de peroneus tertius com fisioterapia
}

Laura Yasmin Monteiro Stancov', Solange Corrêa Mikail

Espaço Equus, Cotia, SP, Brasil

*Autor correspondente

e-mail: lauraymstancov@gmail.com

\section{Resumo}

O músculo peroneus tertius é uma parte importante do aparelho recíproco do equino, responsável por realizar a flexão do tarso de forma simultânea com a articulação femuro-tibio-patelar. A causa mais comum dessa afecção é o trauma. 0 objetivo desse relato é avaliar a resposta ao tratamento de fisioterapia, durante o período de um mês, de um quadro que estava sem evolução por nove meses. Foi enviado ao Espaço Equus um equino macho, da raça Puro Sangue Lusitano, 16 anos de idade, com ruptura parcial da origem do músculo peroneus tertius no membro posterior esquerdo, ocorrida há nove meses, decorrente de um acidente no piquete. A avaliação do caso foi realizada através de ultrassonografia e do aplicativo de análise biomecânica Hudl Technique Elite ${ }^{\circledR}$. No exame ultrassonográfico, a lesão foi identificada próximo à origem e apresentava a estrutura de tamanho aumentado em relação ao membro contralateral, bordos sem definição e áreas hipoecóicas. Na inspeção ao passo, o animal apresentava a biomecânica característica dessa afecção: a flexão da articulação femuro-tibio-patelar sem a flexão concomitante do tarso. 0 ângulo médio de flexão do tarso do membro posterior esquerdo era de 136 graus. 0 programa de fisioterapia consistiu de duas sessões diárias de laser terapêutico Luminex ${ }^{\circledR}$ na dose de $24 \mathrm{~J} / \mathrm{cm}^{2}$, durante 26 dias. Foi realizado também um programa de exercícios progressivos que incluiu: duas caminhadas de dez minutos ao passo por dia, exercício ativo assistido para a flexão do tarso (realizado dentro da baia através da estimulação da pele no membro afetado) e exercícios ao passo com estimulador de banda coronária (técnica descrita pela Dra. Hilary Clayton para gerar um estímulo proprioceptivo através do uso de uma pulseira com argolas na quartela, para aumentar a flexão do tarso). Aos vinte dias, foram inclusos os exercícios com uma sequência de cinco obstáculos em forma de cavalete (dez repetições) e aumento na altura dos obstáculos para $15 \mathrm{~cm}$ nos últimos cinco dias. Em apenas trinta dias, observou-se uma melhora expressiva na flexão da articulação do tarso. Inicialmente, o grau de flexão máximo do tarso era de 110 graus; após um mês de tratamento foi 
para 57 graus. A avalição ultrassonográfica também apresentou melhora: a estrutura apresentou tamanho menor, bordos mais definidos e aumento da ecogenicidade. Conclui-se que a fisioterapia contribuiu nesse caso não só na melhora clínica, mas também no tempo de recuperação, pois o animal apresentava incapacidade de flexionar o tarso há nove meses, e em apenas trinta dias, voltou a flexioná-lo.

Palavras-chave: Peroneus tertius. Fisioterapia. Reabilitação. 